\title{
STUDI TENTANG PENDIDIKAN SEKS DAN PERILAKU SEKSUAL PADA REMAJA DI SMPN 2 KREMBUNG
}

\author{
Tetty Rihardini \\ Prodi DIII Kebidanan, Universitas PGRI Adi Buana Surabaya
}

\begin{abstract}
ABSTRAK
Kehidupan seks bebas telah merebak ke kalangan kehidupan remaja dan anak.Maraknya tayangan pornografi dan pornoaksi di tengah masyarakat mempengaruhi merebaknya penyimpangan seksual di kalangan pelajar. Indonesia sehat tahun 2010 memiliki target menurunkan prevalens, permasalahan remaja secara umum termasuk target remaja mendapatkan akses pelayanan reproduksi remaja melalui jalur sekolah.Pendidikan seks bertujuan anak dapat melewati masa pra reproduksi terhindar dari perilaku yang menyimpang dari moral maupun kehidupan seksual yang tidak sehat. Hasil penelitian ini diharapkan menjadi bahan masukan untuk kebijakan dalam memberikan informasi tentang kesehatan reproduksi remaja khususnya pendidikan seks.

Desain penelitian digunakan metode penelitian deskriptif dengan pendekatan cross sectional. Populasi dalam penelitian ini adalah sebagian siswa SMPN 2 Krembung kelas IX. Sampel sebanyak 67 responden. Teknik sampling total sampling. Variabel pada penelitian ini adalah Pendidikan Seks dan Perilaku Seksual Remaja. Data diambil dengan pengisian kuesioner berisi 26 pertanyaan. Teknik analisis data menggunakan deskriftif persentase dan metode statistic Chi Square dengan instrument SPSS 2.0.

Hasil penelitian diperoleh bahwa dari59 (88,06\%) responden sebagian besar mendapatkan informasi seks, 35 (24\%) responden sebagian besar mendapat informasi seks dari lingkungan sekolah yaitu guru dan perpustakaan.Hampir seluruh responden menyatakan mendapatkan pendidikan seks.Hampir seluruh responden memiliki perilaku seksual tidak beresiko.Hasil uji hipotesis dengan statistik chi square didapatkan p-value sebesar 0,341 dan nilai chi squarenya sebesar 0,906. Karena nilai signifikansi 0,341 $>(0,05)$ maka tidak ada hubungan antara pendidikan seks dengan perilaku seksual remaja di SMPN 2 Krembung.

Peran serta tenaga kesehatan dalam pendidikan seksual pada remaja sangat minim. Perlu ditingkatkan lagi KIE tentang pendidikan seksual yang baik dan benar dari sisi kesehatan oleh tenaga kesehatan.
\end{abstract}

Kata Kunci :Pendidikan seks, Perilaku seksual remaja

\section{PENDAHULUAN}

\section{Latar Belakang}

Remaja merupakan populasi yang besar dari penduduk dunia. WHO mendefinisikan remaja sebagai periode usia 10-19 tahun. Remaja adalah generasi penerus yang merupakan aset / modal utama sumber daya manusia bagi pembangunan bangsa. Masa remaja adalah periode kehidupan yang penuh dinamika, terjadi perkembangan dan perubahan yang sangat pesat. Periode masa transisi dari masa anak-anak menuju masa dewasa. Pada saat ini remaja mempunyai resiko tinggi terhadap gangguan tingkah laku, kenakalan, terjadinya kekerasan baik sebagai korban maupun sebagai pelaku dari tindak kekerasan (Soetjiningsih, 2004 : 241).
Kehidupan seks bebas telah merebak ke kalangan kehidupan remaja dan anak. Mestika (1996) yang merangkum hasil penelitian para pengamat masalah sosial remaja di beberapa kota besar. Penelitian tersebut antara lain : Sarwono (1970) meneliti 117 remaja di Jakarta dan menemukan bahwa $4,1 \%$ pernah melakukan seks. Beberapa tahun kemudian, Eko (1983) meneliti 461 remaja dan dari penelitian ini remaja pernah melakukan hubungan seks pra nikah. Di Semarang, Satato (1992) mengadakan penelitian terhadap 1086 responden pelajar SMP-SMUN dan menemukan data bahwa $4,1 \%$ remaja putra dan $5,1 \%$ remaja putri pernah melakukan hubungan seks. 
Saat ini, banyak orang tua menyerahkan sepenuhnya pendidikan anaknya pada sekolah, termasuk pendidikan moral etika pergaulan yang memberikan rambu-rambu agar siswa tidak terjerumus dalam perilaku seksual menyimpang. Sementara itu, dengan adanya keterikatan dan batasan kurikulum membuat lembaga pendidikan tidak dapat memenuhi harapan orang tua.

Padahal maraknya tayangan pornografi dan pornoaksi di tengah masyarakat mempengaruhi merebaknya penyimpangan seksual di kalangan pelajar, dan memerlukan penanganan serius. Selain penanaman nilai-nilai luhur yang dapat mengendalikan nafsu yang merusak, pengetahuan tentang kesehatan reproduksi perlu diberikan, agar anak dapat mengetahui cara memelihara dan melindungi organ-organ reproduksinya. Dengan cara menjaga kesehatan atau melindungi organ-organ reproduksinya ketika anak menginjak remaja, seperti khitan (bagi laki-laki), bersuci dari menstruasi (termasuk membersihkan organ vitalnya), batas-batas pergaulan dengan lawan jenis dan akibat pergaulan bebas bagi kesehatan reproduksi. Teknologi informasi dan penyajian komoditas seks yang tidak wajar cenderung vulgar dan menyesatkan perlu diimbangi dengan pendidikan seksual yang benar. Namun hal ini jarang dilakukan, karena masih sering menimbulkan kontroversi (Sukti, 2003).

Sebagian orang tua memandang pengetahuan tentang reproduksi itu identik dengan pendidikan seks. Sehingga mereka menentang diberikannya pendidikan reproduksi sehat bagi remaja. Persepsi dan sikap semacam ini juga ada pada sebagian dosen atau guru. Di sisi lain sebagian orang tua / guru / dosen, menginginkan adanya pendidikan reproduksi sehat masuk dalam kurikulum, agar anak dapat melewati masa pra reproduksi (sebelum menikah) itu dengan "Selamat dan Sehat" artinya terhindar dari perilaku yang menyimpang dari moral maupun kehidupan seksual yang tidak sehat (Sukri, 2003).

Untuk pelayanan kesehatan reproduksi remaja, Indonesia sehat tahun 2010 memiliki target menurunkan prevalens, permasalahan remaja secara umum termasuk target remaja mendapatkan akses pelayanan reproduksi remaja melalui jalur sekolah (Sparie, 2005).

SMPN 2 Krembung berlokasi di Kabupaten Sidoarjo perbatasan. Menurut informasi dari guru BP di SMPN 2 Krembung yang menyatakan bahwa terindikasi perilaku seksual remaja di sekolah ini mulai mengarah beresiko. Berdasarkan fenomena yang terjadi secara global, penulis tertarik meneliti pendidikan seks dan perilaku seksual remaja di SMPN 2 Krembung.

\section{Rumusan Masalah}

"Bagaimanakah pengaruh pendidikan seks dan perilaku seksual pada remaja di SMPN 2 Krembung Kecamatan Sidoarjo.”

\section{METODE PENELITIAN}

\section{A. Desain Penelitian}

Desain penelitian yang digunakan pada penelitian ini adalah deskriftif. dengan pendekatan cross sectional.

\section{B. Waktu dan Tempat Penelitian}

Waktu penelitian dilakukan pada bulan Januari sampai dengan Februari 2016, sedangkan tempat penelitian dilakukan di SMPN 2 Krembung.

\section{Kerangka Kerja Penelitian}




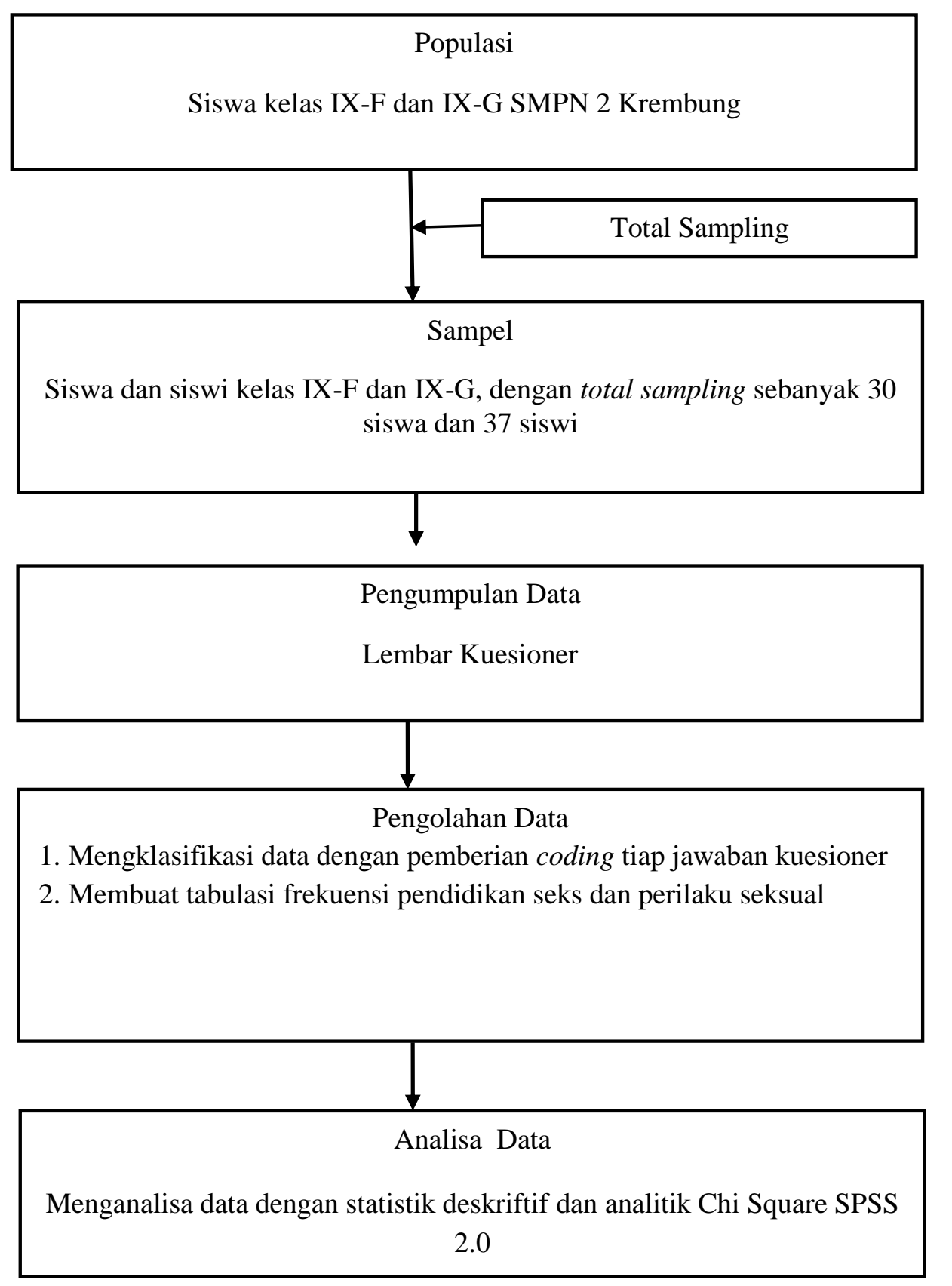

Gambar 4.1. Kerangka Kerja Penelitian Studi Pendidikan Seks dan Perilaku Seksual Remaja di SMPN 2 Krembung 


\section{Populasi, Sampel, Besar Sampel dan Sampling}

1. Populasi Penelitian

Populasi dalam penelitian ini adalah seluruh siswa kelas IX di SMPN 2 Krembung

2. Sampel Penelitian

Sampel dalam penelitian ini adalah sebagian populasi yaitu kelas IX-F dan IXG. Besar sampel sebanyak 67 orang.

3. Teknik Sampling.

Teknik sampling yang dipakai pada penelitian ini adalah total sampling, seluruh siswa dan siswi kelas IX-F dan IXG SMPN 2 Krembung.

\section{E. Identifikasi Variabel}

Variabel pada penelitian ini adalah pendidikan seks dan perilaku seksual remaja.

\section{F.Instrumen Penelitian}

Pada penelitian ini instrumen yang digunakan adalah kuesioner.

\section{G. Pengumpulan Data dan Analisa Data}

\section{Pengumpulan Data}

Teknik pengumpulan data dalam penelitian ini menggunakan kuesioner yang disodorkan pada responden. Kuesioner berisi tentang pertanyaan pendidikan seks dan perilaku seksual remaja.

\section{Analisa Data}

Data yang diperoleh selanjutnya dilakukan pengolahan data sebagai berikut: 1) mengumpulkan data, 2) mengklasifikasi data dengan pemberian coding tiap pertanyaan, 3) membuat tabulasi frekuensi tiap pertanyaan, 4) menganalisa data dengan statistik deskriftif presentasi dan menghubungkan dua variabel dengan Chi Square.

\section{HASIL PENELITIAN}

Dalam bab ini diuraikan tentang hasil penelitian yang dilaksanakan di SMPN 2 Krembung pada bulan Januari - Februari 2016, disajikan dalam bentuk tabel.

\section{Jenis Kelamin Responden}

Tabel 5.1 Distribusi Frekuensi Responden Berdasarkan Jenis Kelamin

\begin{tabular}{lcc}
\hline \multicolumn{1}{c}{ Jenis Kelamin } & Jumlah & \% \\
\hline Laki-laki & 30 & 44,8 \\
\hline Perempuan & 37 & 55,2 \\
\hline Total & 67 & 100 \\
\hline
\end{tabular}

Berdasarkan tabel 5.1 responden didapatkan dari dua kelas, yaitu IX-F dan IX-G dengan jumlah 67 responden yang terbagi 30 siswa dan 37 siswi.

\section{Distribusi Frekuensi Mendapat Informasi tentang Seks}

Tabel 5.2 Distribusi Frekuensi Mendapat Informasi tentang Seks

\begin{tabular}{lcc}
\hline \multicolumn{1}{c}{ Informasi tentang Seks } & Jumlah & $\boldsymbol{\%}$ \\
\hline Mendapatkan & 59 & 88,06 \\
\hline Tidak Mendapat & 8 & 11,94 \\
\hline Total & 67 & 100 \\
\hline
\end{tabular}

Berdasarkan tabel 5.2 terdapat 59 $(88,06 \%)$ responden menyatakan pernah mendapatkan informasi. Selebihnya $8(11,94 \%)$ orang menyatakan tidak pernah mendapat informasi tentang seks.

\section{Distribusi Frekuensi Sumber Informasi tentang Seks}

1.3 Tabel Distribusi Frekuensi Sumber Informasi tentang Seks

\begin{tabular}{lcc}
\hline \multicolumn{1}{c}{ Sumber Informasi Seks } & Jumlah & $\mathbf{\%}$ \\
\hline Saudara/keluarga & 10 & 6,9 \\
\hline Orang tua & 15 & 10 \\
\hline Teman & 16 & 11 \\
\hline Pacar & 3 & 2,1 \\
\hline $\begin{array}{l}\text { Lingkungan Sekolah: } \\
\text { Guru / Perpustakaan }\end{array}$ & 35 & 24 \\
\hline Koran/buku/majalah & 27 & 19 \\
\hline Radio/TV/internet & 31 & 22 \\
\hline BKKBN/Dinkes & 6 & 4,2 \\
\hline LSM & 0 & 0 \\
\hline Lainnya & 1 & 0,7 \\
\hline
\end{tabular}

Tabel 5.3 menunjukkan sumber informasi tentang pendidikan seks yang diakses oleh responden terbesar dari lingkungan sekolah 35 
(24\%) orang. Sedangkan dari sumber Radio/TV/Internet hampir sama besar jumlahnya $(22 \%)$.

\section{Distribusi Frekuensi Pendidikan Seks pada Remaja di SMPN 2 Krembung}

Tabel 5.4 Distribusi Frekuensi Pendidikan Seks pada Remaja di SMPN 2 Krembung

\begin{tabular}{lcc}
\hline \multicolumn{1}{c}{ Pendidikan Seks } & Jumlah & \% \\
\hline Diberikan & 52 & 77,6 \\
\hline Tidak diberikan & 15 & 22,4 \\
\hline Total & 67 & 100 \\
\hline
\end{tabular}

Dapat kita lihat dari 67 responden, 52 $(77,6 \%)$ menyatakan telah diberi pendidikan seks. Namun masih ada $15(22,4 \%)$ yang menyatakan tidak diberikan pendidikan seks.

\section{Distribusi Frekuensi Perilaku Seksual pada Remaja di SMPN 2 Krembung}

Tabel 5.5 Distribusi Frekuensi Perilaku Seksual pada Remaja di SMPN 2 Krembung

\begin{tabular}{lcc}
\hline Perilaku Seksual & Jumlah & \% \\
\hline Beresiko & 3 & 4,5 \\
\hline Tidak Beresiko & 64 & 95,5 \\
\hline Total & 67 & 100 \\
\hline
\end{tabular}

Dari tabel 5.5 didapatkan hampir seluruh responden memiliki perilaku seksual tidak beresiko. Namun hal ini masih perlu penelitian lebih lanjut karena kemungkinan besar data yang masuk tidak sepenuhnya pernyataan jujur.

\section{Tabulasi Silang Hubungan Antara Pendidikan Seks dan Perilaku Seksual Pada Remaja di SMPN 2 Krembung}

Tabel 5.6 Tabulasi Silang Hubungan Antara Pendidikan Seks dan Perilaku Seksual Pada Remaja di SMPN 2 Krembung

\begin{tabular}{|c|c|c|c|c|c|c|}
\hline \multirow{3}{*}{$\begin{array}{c}\text { Pendidikan } \\
\text { seks }\end{array}$} & \multicolumn{4}{|c|}{$\begin{array}{c}\text { Perilaku seksual } \\
\text { pada remaja }\end{array}$} & \multirow{2}{*}{\multicolumn{2}{|c|}{ Jumlah }} \\
\hline & \multicolumn{2}{|c|}{$\begin{array}{c}\text { Beresik } \\
\text { o }\end{array}$} & \multicolumn{2}{|c|}{$\begin{array}{c}\text { Tidak } \\
\text { beresiko }\end{array}$} & & \\
\hline & $\Sigma$ & $\%$ & $\Sigma$ & $\%$ & $\Sigma$ & $\%$ \\
\hline Diberikan & 3 & 4,47 & $\begin{array}{l}4 \\
9\end{array}$ & $\begin{array}{c}73,1 \\
3\end{array}$ & $\begin{array}{l}5 \\
2\end{array}$ & 100 \\
\hline $\begin{array}{l}\text { Tidak } \\
\text { diberikan }\end{array}$ & 0 & 0 & $\begin{array}{l}1 \\
5\end{array}$ & $\begin{array}{c}22,3 \\
8\end{array}$ & $\begin{array}{l}1 \\
5\end{array}$ & 100 \\
\hline Jumlah & 3 & 4,47 & $\begin{array}{l}6 \\
4\end{array}$ & $\begin{array}{c}95,5 \\
2\end{array}$ & $\begin{array}{l}6 \\
7\end{array}$ & 100 \\
\hline
\end{tabular}

Berdasarkan hasil perhitungan diatas, maka dapat di ketahui bahwa remaja yang diberikan pendidikan seks berjumlah 52 orang, dengan $3(4,47 \%)$ orang mempunyai perilaku seksual yang beresiko dan tidak seorangpun yang mempunyai perilaku seksual tidak beresiko. Rermaja yang tidak diberikan pendidikan seks berjumlah $15(22,38 \%)$ orang, tanpa seorangpun yang memiliki perilaku seksual beresiko.Dari tabel 5.6 didapatkan $3(4,47 \%)$ orang yang memiliki perilaku seksual beresiko justru pada kolom yang mendapatkan pendidikan seksual.

Hasil uji hipotesis dengan statistik chi square didapatkan p-value sebesar 0,341dan nilai chi squarenya sebesar 0,906 . Karena nilai signifikansi $0,341>(0,05)$ maka hipotesis null diterima yang berarti bahwa tidak ada hubungan antara pendidikan seks dengan perilaku seksual remaja di SMPN 2 Krembung.

\section{PEMBAHASAN}

\section{A. Informasi tentang Seks}

Berdasarkan analisis tabel 5.2 pada bab 5 dapat diidentifikasi bahwa remaja di SMPN 2 Krembung mendapat informasi tentang seks sebanyak $59(88,06 \%)$ orang dan yang tidak mendapat informasi tentang seksberjumlah 8 $(11,94 \%)$ orang.

Sedangkan di tabel 5.3 menjelaskan sumber informasi tentang seks yang didapatkanbervariatif, terbanyak $24 \%$ berasal dari lingkungan sekolah, baik dari guru maupun perpustakaan. Akses informasi bagi remaja pelajar sebaiknya berasal dari lingkup sekolah yaitu guru sebagai perwakilan orang tua, karena materi yang didapatkan pasti sesuai dengan kebutuhan perkembangan psikologi seksualnya.Penyaringan materi informasi, baik secara konten maupun cara penyampaian dapat dipertanggungjawabkan. Hal ini tidak mengecilkan peran orang tua di rumah sebagai sumber utama pengetahuan mereka.

Dari tabel 5.3 menunjukkan hanya 6,9\% responden mendapatkan informasi seks dari orang tua. sebaiknya orang tualah yang paling tepat untuk menyampaikan masalah kesehatan reproduksi dan pendidikan seks kepada anak-anak mereka. Pendidikan seks wajib diberikan orang tua sedini mungkin.

Beberapa faktor yang mempengaruhi kecenderungan orang tua tidak memberikan pendidikan seks pada anak remaja diantaranya: orang tua masih menganggap tabu dan 
ketidaktahuannya untuk menyampaikan pendidikan seks kepada remaja, orang tua belum mengajarkan pendidikan seks sejak dini, ini disebabkan karena orang tua bingung mulai dari mana mengajarkannya kepada anak, faktor ekonomi, karena kesibukan orang tua dalam mencari nafkah untuk memenuhi kebutuhan keluarga, sehingga tidak ada perhatian orang tua bagi perkembangan remaja. Berbagai cara pendekatan perlu ditempuh oleh orang tua untuk mengatasi masalah remaja khususnya menyangkut pengetahuan orang tua tentang pendidikan seks. Tujuannya adalah mengantarkan remaja ke arah kematangan psikologis dan sosial, agar kelak mampu membentuk keluarga yang bertanggung jawab (Betty, 2002).

Namun terdapat $22 \%$ dari responden yang mendapatkan informasi tentang seks berasal dari radio/ TV/ internet. Hampir sama banyaknya dengan jumlah sumber informasi dari lingkungan pendidikan. Bedanya akses ini adalah sumber informasi terbuka, yang artinya remaja bisa mendapatkan konten bebas tak terbatas dan tidak menutup kemungkinan materi pornografi juga bisa didapatkan tanpa pengawasan ataupun pantauan orang tua. Mereka akan mendapatkan kebebasan mendapatkan informasi yang diinginkan.

Pada media internet mudah saja mengakses materi yang bersifat pornografi, dengannakibat dapat menguasai pikiran remaja yang kurang kuat dalam menahan pikiran emosinya karena belum boleh melakukan hubungan seks yang sebenarnya. Semakin sering seseorang berinteraksi dengan pornografi maka akan semakin beranggapan positif terhadap hubungan seks secara bebas. Namun apabila internet di gunakan secara sehat maka akan berdampak baik pada penggunanya (Fitriana,2009).

Para remaja memperoleh informasi mengenai seks dan seksualitas dari berbagai sumber, termasuk dari teman sebaya, lewat media massa baik cetak maupun elektronik termasuk di dalamnya iklan, buku, ataupun situs internet yang khusus menyediakan informasi tentang seks.

Menurut peneliti orang tua hendaknya berperan sebagai pendidik terutama memberikan pendidikan seks yang baik dan benar kepada remaja. Ketidakpekaan orang tua dan pendidikan terhadap kondisi remaja menyebabkan remaja sering terjatuh pada kegiatan tuna susila, karena remaja canggung dan enggan untuk bertanya kepada orang yang tepat, semakin menguatkan alasan kenapa remaja sering salah dan tidak tepat menggunakan organ reproduksinya.

Selain itu dampak yang berpengaruh pada remaja yaitu arus globalisasi yang semakin tidak terbatas, contoh kecil kasus pornografi dan pornoaksi. Rasa ingin tahu ini membuat remaja cenderung mencari tahu melalui VCD, buku, foto, majalah, internet, dan sumber-sumber lain yang belum tentu cocok untuk remaja. Sumber informasi yang didapat oleh remaja dapat memberikan substansi yang salah dan menyesatkan. Buku, majalah, film, dan internet yang mereka akses cenderung bermuatan pornografi, bukan pendidikan reproduksi.

\section{B. Pendidikan Seks}

Pendidikan seks adalah suatu informasi mengenai persoalan seksualitas manusia yang jelas dan benar, yang meliputi proses terjadinya pembuahan, kehamilan sampai kelahiran, tingkah laku seksual, hubungan seksual, aspek-aspek kesehatan, kejiwaan dan kemasyarakatan. Masalah pendidikan seksual yang di berikan sepatutnya berkaitan dengan norma-norma yang berlaku di masyarakat, apa yang di larang, apa yang dilazimkan bagi pelakunya tanpa melanggar aturan yang berlaku di masyarakat (Sarlito, 1994).

Berdasarkan uraian di atas dapat dijelaskan bahwa pendidikan seksual merupakan cara pengajaran atau pendidikan yang dapat menolong remaja untuk menghadapi masalah hidup yang bersumber pada dorongan seksual. Dengan demikian pendidikan seksual ini bermaksud untuk menerangkan segala hal yang berhubungan dengan seks dan seksualitas dalam bentuk yang wajar.

Dari Tabel 5.4 sebayak $52(77,6 \%)$ orang menyatakan telah diberi pendidikan seks dan 15 $(22,4 \%)$ orang sisanya menyatakan tidak diberikan pendidikan seks. Berbeda dengan pengakuan guru BP saat peneliti melakukan pengambilan data, mereka menyatakan bahwa pendidikan seks sudah di berikan dalam batasan materi pengenalan organ reproduksi dan tata cara pergaulan remaja. Namun ternyata masih ada yang merasa tidak mendapatkan pendidikan seks. Menurut pertanyaan dalam kuesioner tentang pendidikan seks, di dapatkan data $45(67,16 \%)$ menjawab pendidikan seks di berikan di sekolah, $22(32,84 \%)$ sisanya tidak merasa diberi pendidikan seks di sekolah. Lebih menariknya lagi hanya $16(23,88 \%)$ responden mengaku diberikan pendidikan seks oleh orang tua. Padahal 
seharusnya pendidikan seks akan lebih berpengaruh jika di berikan secara dini dan dilakukan dalam konteks keluarga dengan pendekatan kasih sayang.

Penting menyampaikan kepada para remaja, dalam hal ini siswa dan siswi SMPN 2 Krembung bahwa pendidikan seks bukanlah melulu materi seputar hubungan badan ataupun hal yang berbau pornografi. Pendidikan seks adalah suatu cara untuk mencegah atau mengurangi penyalahgunaan seks, khususnya untuk mencegah dampak - dampak negatif yang tidak diharapkan seperti kehamilan yang tidak diinginkan, penyakit menular seksual, depresi dan perasaan berdosa. Tidak kalah pentingnya peran keluarga -dalam hal ini orang tua- sebagai tingkat pertama dalam proses pendidikan seks yang mampu membentuk kekuatan mental dan spiritual.

\section{Perilaku Seksual}

Perilaku seksual adalah segala tingkah laku yang didorong oleh hasrat seksual, baik dengan lawan jenisnya maupun dengan sesama jenis. Dalam hal ini, perilaku seksual adalah remaja dapat diwujudkan dalam tingkah laku yang bermacam-macam, mulai dari perasaan tertarik sampai tingkah laku kencan, bercumbu dan bersenggama. Objek seksualnya bisa berupa orang lain, orang dalam khayalan atau diri sendiri (Eliyawati, 2004). Berdasarkan uraian di atas dapat di jelaskan bahwa perilaku merupakan hasil hubungan antara perangsang (stimulus) dan tanggapan (respon).

Berdasarkan tabel 5.5 dapat dijelaskan bahwa distribusi frekuensi perilaku seksual pada remaja di SMPN 2 Krembung yang beresiko berjumlah $3(4,5 \%)$ orang dan yang perilaku seksual tidak beresiko berjumlah 64 (95,5\%) orang. Hasil penelitian ini belum merefleksikan kondisi nyata. Karena menurut penturan guru BP, bahwa dikelas yang diambil menjadi sampel penelitian ini sebelumnya didapatkan beberapa kejadian yang melanggar tata tertib sekolah berkaitan dengan perilaku seksual yang beresiko. Besar kemungkinan data yang diberikan tidak sesuai dengan kondisi yang pernah dialami, dikarenakan perasaan malu tidak ingin diketahui oleh guru ataupun teman di sebelahnya. Bisa jadi perilaku seksual mereka sebenarnya lebih ekstrim dari pernyataan mereka di kuesioner.

Terlepas dari hal tersebut, untuk penelitian kedepan dibutuhkan teknik pengumpulan data yang lebih aman dan menjaga privacy responden agar jawaban yang diberikan lebih jujur sesuai dengan kondisi yang dialami.

\section{Hubungan Antara Pendidikan Seks dan Perilaku Seksual pada Remaja}

Berdasarkan hasil perhitungan tabulasi silang Tabel 5.6, maka dapat di ketahui bahwa remaja yang diberikan pendidikan seks berjumlah 52 orang, dengan $3(4,47 \%)$ orang mempunyai perilaku seksual yang beresiko dan tidak seorangpun yang mempunyai perilaku seksual tidak beresiko. Rermaja yang tidak diberikan pendidikan seks berjumlah $15(22,38 \%)$ orang, tanpa seorangpun yang memiliki perilaku seksual beresiko. Dari tabel 5.6 didapatkan $3(4,47 \%)$ orang yang memiliki perilaku seksual beresiko justru pada kolom yang mendapatkan pendidikan seksual. Berdasarkan uraian di atas dapat di jelaskan bahwa sebagian siswa /siswi SMPN 2 Krembung berperilaku seksual tidak beresiko, hal itu dapat di sebabkan mereka diberikankan pendidikan seks, dari orang tua maupun melalui guru, teman dekat dan media-media yang ada.

Secara garis besar perilaku seksual pada remaja di sebabkan oleh beberapa faktor antara lain : agama, budaya, adat istiadat, sosial, dan ekonomi.Perilaku seksual adalah tindakan yang di lakukan seseorang berdasarkan keinginannya terhadap sesuatu yang di pengaruhi oleh faktor internal maupun eksternal dan bisa timbul perilaku seksual salah satunya karena pergaulan semakin bebas (Sarwono, 2006).

Pada usia ini remaja lebih mudah untuk menerima informasi dari luar khususnya tentang kesehatan reproduksi dan seksual, maka sumber informasi yang baik akan berpengaruh pada pengetahuan yang baik (Fitriana,2009). Selain itu menurut Piaget dalam Santrock (2003) remaja pada usia ini termotivasi untuk memahami dunia, secara aktif remaja membangun dunia kognitif mereka dengan cara mencari informasi sebanyak banyaknya, sehingga merekadapat memahami bahwa tindakan yang dilakukan saat ini dapat memiliki efek pada masa yang akan datang dengan demikian mereka mampu memperkirakan konsekuensi dari tindakannya termasuk adanya kemungkinan yang dapat membahayakan dirinya.

Hasil uji hipotesis dengan statistik chi square didapatkan $p$-value sebesar0,341dan nilai chi squarenya sebesar 0,906.Karena nilai signifikansi $0,341>(0,05)$ maka hipotesis null diterima yang berarti bahwa tidak ada hubungan 
antara pendidikan seks dengan perilaku seksual remaja di SMPN 2 Krembung. Karena hasil penelitian ini tidak sesuai dengan teori yang menyatakan bahwa pendidikan seks akan berpengaruh positif dengan perilaku seksual, bukan berarti dengan diberikannya pendidikan seksual akan mengarahkan remaja untuk berperilaku seksual beresiko. Namun konten yang perlu di teliti lagi adalah cara melakukan pengambilan data yang lebih menjaga privacy responden sehingga bisa menjawab pertanyaan dengan jujur dan tanpa takut ataupun malu diketahui oleh pihak lain.

Selain itu Hyde (1990) mengatakan bahwa salah satu faktor yang mempengaruhi perilaku seks adalah media massa, kecenderungan pelanggaran makin meningkat oleh karena adanya penyebaran informasi dan rangsangan seksual melalui mediamassa yang dengan adanya tekhnologi yang semakin berkembang (video, HP, internet). Remaja selalu ingin tahu dan ingin mencoba, bahkan meniru apa yang dilihat atau didengarnya dari media massa. Namun hal ini dapat berdampak positif apabila informasi yang didapat baik dan benar. Dalam penelitian ini sebagian besar responden mendapatkan informasi dari media massa dan internet, selain memperoleh dari guru, buku di perpustakaanmaupun dari sumber lain.

Adanya informasi yang baik dan benar, dapat menurunkan permasalahan seksual pada remaja. Dengan demikian, meskipun hasil penelitian ini dapat dikatakan tidak ada hubungan antara pendidikan seks dan perilaku seksual remaja di SMPN 2 Krembung namun perlu di ingat bahwa semakin tinggi tingkat pengetahuan remaja melalui pendidikan maka akan semakin baik perilakunya, karena pengetahuan atau kognitif merupakan domain yang sangat penting untuk terbentuknya tindakan seseorang (overt behavior).Pendidikan seks tetap harus diberikan sesuai dengan tingkat perkembangan anak, tujuannya adalah memberikan bekal pengetahuan serta membuka wawasan anak-anak remaja seputar masalah seks secara benar dan jelas. Berarti seks yang benar menghindarkan mereka dari berbagai resiko negatif seperti kehamilan di luar nikah, pelecehan seksual, dan penyakit menular seksual.

Pendidikan seks yang menjadi inti kegiatan konsultasi merupakan bagian yang integral dari pendidikan kepribadian secara menyeluruh. Yang paling bertanggung jawab dalam memberikan pendidikan seks kepada remaja adalah orang tua, selanjutnya oleh guru disekolah serta masyarakat dilingkungannya. Kontradiksi pemberian pendidikan seksual di Indonesia menjadikan pertentangan mereka antara citra tabu dan seksualitas sebagai ilmu yang harus diketahui. Pendidikan seksual yang dimaksudkan adalah kegiatan pendidikan yang berusaha untuk memberikan pengetahuan agar mereka dapat mengubah perilaku seksualnya kearah yang lebih bertanggung jawab.

Usaha-usaha lain yang sifatnya preventif dapat pula dilakukan melalui pendidikan informal (keluarga), pendidikan informal (sekolah), dan juga melalui pendidikan non formal (masyarakat). Pembinaan pendidikan keluarga dapat berupa: menghindari keretakan rumah tangga (broken home atau broken family), menanamkan pendidikan agama yang sesuai dengan tingkat perkembangannya misalnya keimanan, akhlak, dan ibadah, pemeliharaan hubungan kasih sayang yang adil dan merata, antara sesama anggota keluarga, pengawasan yang intensif terhadap gejala aktivitas yang dilakukan oleh anak-anak untuk menekan kemungkinan berperilaku negatif. pemberian kesibukan yang bermanfaat dan tanggung jawab, pembagian peranan dan tanggung jawab diantara para anggota keluarga.

Pembinaan pendidikan formal (sekolah), sekolah sebagai lingkungan kedua setelah keluarga memegang peranan yang sangat penting, terutama dalam pembinaan sikap mental, pengetahuan dan keterampilan anak. Sasaran pembinaan ini adalah tumbuhnya remaja-remaja yang dinamis, kritis dalam berpikir dan bertindak. Keadaan ini akan memperkecil frekuensi terjadinya penyimpangan. Usaha pendekatannya antara lain: mengintensifkan pelajaran agama. Mengadakan pembenahan dan pemenuhan sarana dan prasarana pendidikan. penerapan metodologi mengajar dan belajar yang efektif, menarik minat dan perhatian anak, sehingga anak belajar lebih aktif, dalam pelaksanaan kurikulum hendaknya memperhatikan keseimbangan aspek kognitif, efektif dan psikomotor yang memadai. peningkatan pengawasan dan disiplin terhadap tata tertib sekolah, mengadakan identifikasi dan bimbingan mengenai bakat, minat, kemampuan, dan penyalurannya, dan melatih atau membiasakan anak untuk dapat bekerjasama, berorganisasi dengan bimbingan guru melalui organisasi sekolah, misalnya OSIS dan lainlainnya, mengadakan tenaga guru agama yang ahli dan berwibawa serta mampu bergaul dengan 
guru-guru lain, sehingga bisa ditiru oleh muridmuridnya, adanya kesamaan norma-norma yang dipegang oleh guru- guru, serta adanya kekompakan para guru.

Pembinaan pendidikan non formal (masyarakat). Masyarakat adalah tempat pendidikan yang ketiga sesudah rumah tangga dan sekolah. pembinaan- pembinaan pendidikan kemasyarakatan dimaksudkan untuk mengisi waktu senggang dengan kegiatan yang bermanfaat. Hal itu dapat dilakukan dengan jalan meningkatkan pendidikan kepramukaan, penyuluhan mental agama, pendidikan keterampilan, pembinaan olah raga, usaha-usaha perluasan perpustakaan, Palang Merah remaja, Karang Taruna, remaja mesjid, dan usahausaha lainnya.

Pada akhirnya usia remaja merupakan usia yang sangat labil dan sedang dalam proses pencarian identitas diri. Pergaulan remaja yang semakin bebas salah satu dampak yang perlu mendapat perhatian. Kini telah menjurus kepada perilaku seksual secara bebas dan tidak bertanggungjawab. Peran orang tua sangatlah signifikan terhadap perkembangan remajanya, orang tua yang cenderung tertutup, tidak bisa memberikan arti penting pendidikan seks bagi remaja, maka akan berakibat pada pergaulan bebas bagi remaja. Semestinya disini peran orang tua sangat dibutuhkan putra-putrinya yang menginjak usia remaja.

\section{KESIMPULAN}

Berdasarkan pada hasil penelitian dapat disimpulkan bahwa:

1. Dari $59(88,06 \%)$ responden sebagian besar mendapatkan informasi seks.

2. Dari 35 (24\%) responden sebagian besar mendapat informasi seks dari lingkungan sekolah yaitu guru dan perpustakaan.

3. Hampir seluruh responden menyatakan mendapatkan pendidikan seks.

4. Hampir seluruh responden memiliki perilaku seksual tidak beresiko.

5. Hasil uji hipotesis dengan statistik chi square didapatkan $p$-value sebesar0,341dan nilai chi squarenya sebesar 0,906.Karena nilai signifikansi $0,341>(0,05)$ maka hipotesis null diterima yang berarti bahwa tidak ada hubungan antara pendidikan seks dengan perilaku seksual remaja di SMPN 2 Krembung.

\section{SARAN}

1. Bagi peneliti lebih mengembangkan metode penelitian dengan cara penyebaran kuesioner secara individu untuk melindungi privacy responden, sehingga jawaban yang diberikan bisa lebih jujur.

2. Berdasarkan hasil kuesioner, peran serta tenaga kesehatan dalam pendidikan seksual pada remaja sangat minim. Perlu ditingkatkan lagi KIE tentang pendidikan seksual yang baik dan benar dari sisi kesehatan oleh tenaga kesehatan.

\section{DAFTAR PUSTAKA}

Arikunto, S.2006.Penelitian Suatu Pendekatan Praktek. Jakarta : Rineka Cipta.

Betty, S.2002.Pendidikan Perilaku Seks Remaja. Jakarta. www.google.co.id

Dianawati,A. 2003. Pendidikan Seks untuk Remaja. Jakarta : Kawan Pustaka

Gunoto, 2005.Persepsi Seks Bebas di Kalangan Remaja.www.bkkbn.co.id

Hady. 2009. Pendidikan Seks Upaya Preventif Perilaku Seksual Pranikah. http://.wordpress.com/2009/02/24/pe ndidikan-seksupaya-preventifperilakuseksual-pra-nikah/. Diakses pada Tanggal 10 Maret 2016.

Hurlock, E.B. 2000. Psikologi Perkembangan: Suatu Pendekatan Sepanjang Rentang Kehidupan. Jakarta: Erlangga.

Hyde, J.S. 1990. Understanding Human Sexuality. Saint Louis : Mc GrawHill, inc.

Irawati, I.1999. Modul Perkembangan Seksualitas Remaja. Bandung : PKBI - UNFPA.

Ircham,M. 2005. Pendidikan Kesehatan Bagian Dari Promosi Kesehatan.Yogyakarta: Fitra Maya.

Luthfie, R.E. 2009. Fenomena Perilaku Seksual Pada Remaja (Sexual Behaviour Phenomena on Young People), Jurnal Ceria.

Notoatmodjo, S.2005.Metodologi Penelitian Kesehatan. Jakarta : Rineka Cipta.

Nursalam,S.P.2001.Metodologi Riset Keperawatan. Jakarta : Infomedika. 
Santrock, J.W. 2003. Adolescence : Perkembangan Remaja. Alih bahasa oleh : Shinto B.A dan S. Saragih. Jakarta : Erlangga.

Sarwono, S.W.2010.Psikologi Remaja. Jakarta : Raja Grafindo Persada

Soedjiningsih.2004.Tumbuh Kembang Remaja dan Permasalahannya . Jakarta : Sagung Seto.

Soetjiningsih. 2008. Perilaku seksual pranikah pada remaja Usia 15 - 18 Tahun. Jurnal Kesehatan Masyarakat, Maret 2008 - September 2008, II (2).

Subandowo.2010.Pedoman Penelitian. Surabaya : UNIPA

Sugiono.2009. Statistika untuk Penelitian. Bandung : Alfabeta

Yusuf, S.2010.Psikologi Perkembangan Anak dan Remaja. Jakarta : Remaja Rosda Karya. 